\title{
Hubungan Antara Kebersyukuran Dan Subjective Well-Being Pada Perawat Wanita Dan Bidan Di Rsu Sis Al-Djufrie Palu
}

\author{
Muhammad Shodikul Haq, Ahmad Muhammad Diponegoro, Purwadi \\ Universitas Ahmad Dahlan, Yogyakarta, Indonesia. \\ Email: mshodikulhaqpsy@gmail.com
}

\begin{abstract}
This research aims to determine the relationship between Gratefulness and Subjective Well-Being. The research subjects used in this research were 34 female nurses and midwives at Sis Al-Djufrie Hospital, Palu City. This research uses quantitative methods. Data obtained instrument from a scale to measure Gratitude questionnaire to see the life-size of the subject and the Positive affect negative affect schedule-Expanded form scale to measure positive and negative effects on individuals and use the Satisfaction with Life Scale to measure the level of individual life satisfaction. Analysis of the data used is using Pearson Product Moment correlation. The result of data analysis showed a correlation coefficient of 0.655 with a significance of $0.000(p<0.05)$ and showed a very significant positive relationship between thanksgiving and Subjective Well-Being. The results of this study indicate that the contribution given by gratitude to the Subjective Well-Being is 42.9 percent, this indicates a very significant relationship between the variables of Gratitude and Subjective Well-Being towards female nurses and midwives.
\end{abstract}

Keywords: female nurse, midwive, Subjective Well-Being, Gratitude

\begin{abstract}
Abstrak
Penelitian ini tujuan untuk mengetaui hubungan antara Kebersyukuran dengan Subjective Well-Being. Subjek penelitian yang digunakan dalam penelitian ini perawat wanita dan bidan di RSU Sis Al-djufrie kota palu berjumlah 34 orang. Penelitian ini menggunakan metode kuantitatif. Instrumen pengumpulan data terdiri dari kuesioner Kebersyukuran untuk melihat kebersyukuran hidup subjek dan skala Positive affect negative affectschedule-Expanded form untuk mengukur afek positif dan negatif pada individu serta menggunakan Statisfatction with Life Scale untuk mengukur tingkat kepuasan hidup individu. Analisis data yang digunakn adalah menggunakn Pearson Product Moment Correlation. Hasil analisis data menunjukan koefisien korelasi sebesar 0,655 dengan siginifikansi 0,000 $(\mathrm{p}<0,05)$ dan menunjukan terdapat hubungn positif yang sangat signifikan antara kebersyukuran dengan Subjective Well-Being. Hasil penelitian ini menunjukan bahwa sumbang yang diberikan kebersyukuran terhadap Subjective Well-Being adalah sebesar 42,9 persen, hal ini menunjukan adanya hubungn yangsangat signifikn antar variabel Kebersyukuran dengan Subjective Well-Being terhadap perawat wanita dan bidan.
\end{abstract}

Kata kunci: Perawat wanita, Bidan, Subjective Well-Being, Kebersyukuran.

\section{Pendahuluan}

Dewasa ini wanita telah banyak berpartisipasi dalam dunia pekerjaan seperti halnya laki-laki, hal tersebut berdampak pada peningkatan jumlah pekerja di Indonesia sudah mencapai angka 37,9 persen dari sekitar 102 angakatan kerja (BPS, 2008). Profesi yang sebagian besar digeluti oleh wanita, memiliki tanggung jawab yang berat, dan memiliki jam kerja yang padat antara lain adalah perawat. Pekerjaan perawat wanita dan bidan wanita adalah pekerjaan yang mengutamakan unsur pengabdian dan pelayanan kepada pasien (Depkes, 2011). Perawat merupakan orang pertama dan secara konsisten selama 24 jam menjalin kontak dengan pasien (Hamid \& Yani, 2009). Jika dilihat dari jam kerja dan beban kerja maka pekerjaan sebagai perawat dan bidan adalah salah satu pekerjaan yang sulit dan menimbulkan tingkat stres yang tinggi sedangkan dalam memberikan pelayanan keperawatan/kebidanan membutuhkan hard dan soft skill dalam komposisi yang berimbang. Perawat dan bidan wanita seperti halnya profesi lain dituntut mampu menyediakan pelayanan secara profesional (Sabiq \& Miftahuddin, 2017). Kondisi apapun perawat harus dapat bersikap hangat, ramah dan sopan pada semua pasiennya sebab pekerjaan mereka termasuk pekerjaan sosial. Kenyataannya banyak perawat wanita dan bidan lebih sering merasakan emosi negatif seperti depresi, khawatir, marah dan sedih hal tersebut membuat banyak perawat menjadi tidak sabar, suka marah, berbicara ketus kepada pasien dan keluarga, bahkan terjadinya kelalaian dalam bekerja seperti kesalahan dalam pemberian obat, dan keterlambatan dalam melakukan injeksi (Setiyana, 2013). Dapat disimpulkan

Diterima Redaksi : 20-10-2020 | Selesai Revisi : 26-04-2021 | Diterbitkan Online : 28-04-2021 
bahwa emosi negatif yang sering dirasakan oleh perawat membuat mereka tidak merasakan kesejahteraan dalam hidupnya.

Kesejahteraan subjektif sering disebut dengan Subjective well-being. Subjective well-being menurut Diener, Lucas dan Oishi (2016) diartikan sebagai penilaian individu terhadap kehidupannya yang meliputi penilaian kognitif mengenai kepuasan hidup dan penilaian afektif mengenai perasaan dan emosi. Perawat yang memiliki subjective well-being yang tinggi lebih mampu merasakan emosi positif dibandingkan emosi negatif sebaliknya (Qadariah \& Garnida, 2017). Sejalan dengan penelitain tersebut Qu dan Wang (2015) menyatakan bahwa perawat kurang merasakan emosi positif sehingga tidak merasakan kepuasan hidup. Penelitian yang dilakukan oleh Mutlu dan Ozturk (2010) menyatakan bahwa perawat yang memiiki subjective well-being yang tinggi dapat menurunkan kecemasan sosialnya. Oleh sebab itu perawat lebih dapat mengelolah, mempertahankan persahabatan, hubungan romantis, dan pernikahan yang dapat membantu mereka menjalankan perannya sebagai perawat secara optimal (Diener \& Pavot, 2009).

Setiap agama mempunyai kitab suci yang dianggap sebagai petunjuk hidup secara positif (Diponegoro, 2008). Seligman (Diponegoro, 2008) mengatakan bahwa nilai-nilai ajaran agama yang terkandung dalam pelbagai kitab suci berpotensi untuk meningkatkan subjective well-being. Begitu pula dalam agama Islam dan salah satu nilai ajaran dalam agama Islam adalah Kebersyukuran. Kebersyukuran adalah perasaan pengalaman emosional waktu nyata seperti rasa terima kasih dan kegembiraan dalam menanggapi menerima hadiah (McCullough, Emmons \& Tsang, 2004). Penelitian dari Ramzan dan Rana (2014) mengatakan bahwa adanya hubungan yang positif antara kebersyukuran dan kesejahteraan subjektif. Penelitian yang dilakukan oleh Buragohain dan Mandal (2015) menyatakan bahwa kebersyukuran terbukti berkorelasi positif dengan kepuasan terhadap hidup serta afek positif sebagai aspek dari kesejahteraan subjektif. Pada penelitian yang dilakukan oleh Overwalle (Mukhlis \& Koentjoro, 2015) mengungkapkan orang dengan rasa syukur yang tinggi mengalami kebahagiaan yang lebih besar, harapan, dan kebanggaan yang lebih besar dibandingkan orang yang kurang bersyukur.

Perawat yang telah berumah tangga tentu saja akan mendapatkan kondisi-kondisi yang menganggu kondisi mentalnya mulai dari sulit membagi waktu dengan keluarga, kematian pasien yang dia tangani, kesalahan saat penanganan pasien ataupun takut tertular penyakit yang berasal dari pasien yang dia tangani, jika hal tersebut dibiarkan terus menerus maka perawat akan lebih sering merasakan emosi negatif namun sebaliknya jika perasaan negatif dapat diubah menjadi positfif perawat akan lebih mudah merasakan kepuasan dalam hidupnya serta mengalami afek positif dibanding individu yang membengun pandangan hidup yang negatif.

Subjective well-being dipandang penting bagi setiap individu dan subjective well-being setiap orang berbeda-beda, begitu juga bagi perawat wanita yang mempunyai pekerjaan yang sulit dari segi waktu ataupun resiko pekerjaan, selau dituntut untuk harus siap bekerja di bawah tekanan. Tekanan-tekanan yang dihadapi oleh perawat dapat menyebabkan tekanan emosi pada perawat, perawat yang lebih sering merasakan emosi positif akan lebih sering bersyukur atas pengalaman-pengalaman hidup yang dia lakukan saat ini.

\section{Metode Penelitian}

Penelitian ini menggunakan metode kuantitatif, dengan instrumen pengumpulan data adalah skala Kebersyukuran untuk melihat kebersyukuran hidup subjek dan skala Positive affect negative affectschedule-Expanded form untuk mengukur afek positif dan negatif pada individu serta menggunakan Statisfatction with Life Scale untuk mengukur tingkat kepuasan hidup individu. Subjek dalam penelitian ini adalah perawat wanita dan bidan yang bekerja di RSU SIS AL-Jufrie kota Palu dengan kriteria yaitu perawat wanita dan bidan yang telah menikah dan beragama islam berjumlah 34 orang. Tekhnik pengambilan sampel pada penelitian ini dengan menggunakan purposive sampling.

\section{Hasil dan Pembahasan}

Tabel 1 Subjective well-being dan Kebersyukuran 


\begin{tabular}{lcc}
\hline & Subjective well-being & Kebersyukuran \\
\hline Skor Minimum & 38 & 123 \\
\hline Skor Maksimum & 119 & 181 \\
\hline Skor Rata-rata & 95.88 & 149.06 \\
\hline Standar Deviasi & 16.591 & 18,14 \\
\hline Kategori Rendah (Persentase) & $1(3 \%)$ & $0(00 \%)$ \\
\hline Kategori Sedang (Persentase) & $11(32 \%)$ & $0(0 \%)$ \\
\hline Kategori Tinggi (Persentase) & $22(65 \%)$ & $34(100 \%)$
\end{tabular}

Berdasarkan hasil kategorisasi dapat dilihat bahwa dari 34 subjek penelitian terdapat 1 subjek (3\%) yang memiliki subjective well-being dalam kategori rendah, 11 subjek $(32 \%)$ dalam, kategori sedang, dan 22 subjek (65\%) dalam kategori tinggi. Hasil ini menunjukkan bahwa subjek dalam penelitian ini memiliki subjective well-being dalam kategori tinggi.

Selanjutnya,kategorisasi skala kebersyukuran dapat dilihat bahwa dari 34 subjek penelitian terdapat 0 subjek $(0 \%)$ yang memiliki kebersyukuran dalam kategori rendah, 0 subjek $(0 \%)$ dalam kategori sedang, dan 34 subjek (100\%) dalam kategori tinggi. Hasil ini menunjukkan bahwa subjek dalam penelitian ini memiliki kebersyukuran dalam kategori tinggi.

Berdasarkan hasiI pengujian Iinearitas, dapat dilihat nilai sig sebesar 0.000 yang mana $p<0.05$, sehinga dapat disimpuIkan bahwa kedua variabeI memiliki hubungan Iinear dan telah memenuhi syarat untuk diIakukan anaIisis Pearson Product Moment CorreIation.

Tabel 2. Hasil Uji Hipotesis

\begin{tabular}{cccc}
\hline Variabel & $\begin{array}{c}\text { Pearson Product } \\
\text { moment }\end{array}$ & $\boldsymbol{R}^{2}$ & Sig \\
\hline $\begin{array}{c}\text { Hubungan antara kebersyukuran dan subjective } \\
\text { well-being }\end{array}$ & 0,655 & 0,529 & 0,000 \\
\hline
\end{tabular}

Sesuai dengan hasil uji hipoteis dengan Pearson Product Moment Correlation pada tabel 2 menunjukan adanya korelasi positif yang sangat signifikan antara kebersyukuran dengan subjective well-being dengan keofisien korelasi sebesar 0,655 dengan tara signifikansi $0,000(p<0,05)$, maka korelasi ini dikategorikan pada hubungan yang kuat (Sugiyono, 2007). Dari hasil penelitian maka dapat dikatakan bahwa ada semakin tinggi kebersyukuran yang dimiliki oleh perawat dan bidan wanit maka akan semakin tinggi pula subjective well-being yang dimiliki perawat wanita dan bidan, sebaliknya.

Berdasarkan hasil analisis sumbangan efektif yang dilakukan didapatkan hasil sumbangan efektif variabel kebersyukuran sebesar 52,9\%. \%. Hasil penelitian ini juga menunjukkan bahwa kebersyukuran berperan positif terhadapt subjective well-being. Hal ini didukung oleh penelitian sebelumnya yang menyatakan bahwa kebersyukuran mempunyai hubungan dengan subjective wellbeing. Paramithasari dan Suseno (2019) memnyatakan bahwa ada hubungan yang sangat signifikan antara kebersyukuran dan subjective well-being. Hasil penelitian Emmons dan Mc Culough (2003) yang menunjukkan bahwa kelompok yang diberikan treatment bersyukur memiliki skor kesejahteraan subjektif yang lebih tinggi dibanding dengan kelompok lainnya. Dalam diskusi penelitian tersebut juga menjelaskan bahwa dengan bersyukur, seseorang akan mendapatkan keuntungan secara emosi dan interpersonal. Hal tersebut dikarenakan perasaan bersyukur dapat menimbulkan emosi yang positif seperti ketenangan batin, hubungan interpersonal yang lebih nyaman, dan juga kebahagiaan (McCullough \& Emmons, 2003). Secara khusus (McCulloughl, Emmons \& Tsang, 2002) menjelaskan bahwa orang-orang yang bersyukur cenderung mengalami emosi poitif lebih sering, menikmati kepuasan dalam hidupnya, dan lebih banyak berharap, serta cenderung jarang mengalami depresi, kecemasan, serta iri hati. Orang yang bersyukur cenderung lebih empati, memaafkan, menolong, dan menunjukkan dukungan terhadap orang lain. 
Kebersyukuran juga mampu meningkatkan kesejahteraan subjektif melalui aspek kepuasan hidup baik kepuasan hidup secara global, maupun kepuasan hidup dalam domain kehidupan. Seseorang yang bersyukur lebih mudah merasakan kepuasan dalam hidupnya dan merasa puas terhadap kondisinya di masa kini maupun di masa lampau. Hal ini sesuai dengan penelitian (Ramzan dan Rana, 2014) tentang ekspresi syukur dan kesejahteraan subjektif pada dosen universitas, yang menyebutkan bahwa seseorang yang bersyukur nampak lebih puas terhadap kehidupannya. Penelitian yang dilakukan oleh Lubis dan Agustin (2018) mengatakan bahwa kebersyukuran mampu meningkatkan subjective well-being pada seseorang. Penelitian yang dilakukan oleh Fitrianur, Situmorang dan Tentama (2018).

\section{Kesimpulan}

Berdasarkan hasil analisis data penelitian maka kesimpulan yang dapat diambil dalam penelitian ini adalah ada hubungan positif yang sangat signifikan antara kebersyukuran dengan subjective well-being pada perawat wanita dan bidan di RSU SIS AL-Djufri Palu. Dimana senmakin tinggi kebersyukuran pada diri seseorang makan semakin tinggi pula subjective well-being pada indidvidu, sebaliknya. Berdasarkan hasil penelitian yang telah diperoleh, peneliti menyarankan beberapa hal sebagai berikut untuk penelitian selanjutnya jumlah sampel diperbanyak dan tidak terbatas perawat wanita dan bidan wanita yang berada pada RSU SIS AL-Djufrie di kota Palu saja tapi juga semua perawat wanita dan bidan di rumah sakit yang berada di kota Palu, sehingga hasil bisa lebih mempresentasikan populasi. Variabel kebersyukuran dalam penelitian ini mempunyai hubungan sangat signiifkan dengan subjective well-being sehingga untuk para perawat dan bidan atau pihak terkait lainnya lebih giat lagi untuk meningkatkan kebersyukuran agar menjadi individu yang lebih baik.

\section{Daftar Rujukan}

[1] Badan Pusat Statistik. (2008). Keadaan angkatan kerja Indonesia. Katalog bps : 2303004

[2] Depkes RI. (2011). Kesehatan Kerja kepada Pekerja. http//:www.depkes.ri.id

[3] Hamid \& Yani.,A. (2009). Bunga rampai asuhan keperawatan jiwa. EGC : Jakarta.

[4] Sabiq, Z., \& Miftahuddin. (2017). Pengaruh optimisme, dukungan sosial, dan faktor demografis terhadap subjective well-being pada perawat. JP31. 6(2).

[5] Setiyana, V. Y. (2013). Forgiveness dan stres kerja terhadap perawat. Jurnal ilmiah psikologi terapan, 1 (2), $2301-8267$

[6] Diener, E., Lucas, R. E. \& Oishi, S. (2016). : The science of happiness and life satisfaction. Dalam C. R. Snyder \& S. J. Lopez (Eds.), Handbook of positive psychology (63-73). New York: Oxford University Press

[7] Garnida, F. A., \& Qadariah, S. (2017) Studai deskriptif mengenai subjectiv well being pada perawat wanita di Rawat Inap RSUP. Dr. Hasan Sadikin Bandung. Prosiding, Vol. 3. No 1.

[8] Qu, H. Y., \& Wang, C. M. (2015). Study on the relationships between nurses' job burnout and subjective well-being. Chinese Nursing Research, 2(2-3), 61-66..

[9] Öztürk, A., \& Mutlu, T. (2010). The relationship between attachment style, subjective well-being, happiness and social anxiety among university students'. Procedia-Social and Behavioral Sciences, 9, 1772-1776.

[10]Diener, E., \& Pavot, W. (2009). Review of the satisfaction with life scale. In Assessing well-being (pp. 101117). Springer, Dordrecht.

[11]Diponegoro, A. M. (2008). Psikologi konseling islami dan psikologi positif. Yogyakarta: UAD Press

[12] McCullough, M. E., Tsang, J. A., \& Emmons, R. A. (2003). Gratitude in Intermediate Affective Terrain: Links of Grateful Moods to Individual Differences and Daily Emotional Experience. Journal of Personality and Social Psychology, 86(2), 295-309. The American Psychological Association, Inc.

[13] Buragohain, P., \& Mandal, R. (2015). Teaching of gratitude among the students of secondary school as a means of weel-being. International Journal of Humanities Social Science and Education. 2(2), 179-188.

[14] Mukhlis, H., \& Koentjoro. (2015). Pelatihan kebersyukuran untuk menurunkan kecemasan meghadapi ujian nasional pada siswa SMA. Gadjah Mada Journal Of Professional Psychology, 1(3), 203-215.

[15] Ramzan, N., \& Rana, S. A. (2014). Expresion of gratitude and subjective wellbeing among university teachers. Middel-East Journal of Scientific Reaserch. 21(5), 756-762.

[16] Sugiyono. 2010. Metode PeneIitian Pendidikn Pendekatn Kuantitatif, kualitatif, dan R\&D. Bandung: CV. Alf

[17] Suseno. M. N., \& Pramithasari. A. (2019). Kebersyukuran dan Kesejahteraan Subjektif pada Guru SMA Negeri I Sewon. Jurnal Penelitian Psikologi, 10(2), 1-12. https://doi.org/10.29080/jpp.v10i2.240

[18] McCullough, M. E., Emmons, R., \& Tsang, J. (2002). The gratefull disposition : a conceptual and empirical topography. Journal Of Personality and Psychology, 82, (1). 112-127.DOI:10.1037//0022-3514.82.1.112 
[19]Lubis, I. R., \& Agustini, L. J. (2018). Efektivitas gratitude training untuk meningkatkan subjective well-being pada remaja di panti asuhan. Jurnal Psikogenesis, 6(2), 205-213.

[20] Fitrianur, F., Situmorang, N. Z., \& Tentama, F. (2018, September). Faktor-Faktor Yang Mempengaruhi Subjective Well-Being Pada Ibu Jalanan. In Temu Ilmiah Psikologi Positif I. Seminar dan Call for Paper" Positive Psychology in Dealing with Multigeneration". Universitas Pertamina Jakarta. Universitas Pertamina Jakarta. 